\title{
Influence of Thickness on Properties of Plasticized Oat Starch Films
}

\author{
Melicia Cintia Galdeano ${ }^{1}$, Allan Eduardo Wilhelm ${ }^{1 *}$, Suzana Mali $^{2}$ and Maria Victória \\ Eiras Grossmann ${ }^{3}$ \\ ${ }^{1}$ Embrapa Agroindústria de Alimentos; Av. das Américas, 29501; 23020-470; Rio de Janeiro - RJ - Brasil. \\ ${ }^{2}$ Departamento de Bioquímica e Biotecnologia; Centro de Ciências Exatas; Universidade Estadual de Londrina; C. \\ P.: 6001; 86051-990; Londrina - PR - Brasil. ${ }^{3}$ Departamento de Ciência e Tecnologia de Alimentos; Centro de \\ Ciências Agrárias; Universidade Estadual de Londrina; C. P.: 6001; 86051-990; Londrina - PR - Brasil
}

\begin{abstract}
The aim of this study was to investigate the effect of thickness (between 80 and $120 \mu \mathrm{m}$ ) on apparent opacity, water vapor permeability and mechanical properties (tensile and puncture) of oat starch films plasticized with glycerol, sorbitol, glycerol:sorbitol mixture, urea and sucrose. Films were stored under 11, 57, 76 and $90 \%$ relative humidity $(R H)$ to study the mechanical properties. It was observed that the higher the thickness, the higher was the opacity values. Films without the plasticizer were more opaque in comparison with the plasticized ones. Glycerol:sorbitol films presented increased elongation with increasing thickness at all RH. Puncture force showed a strong dependence on the film thickness, except for the films plasticized with sucrose. In general, thickness did not affect the water permeability.
\end{abstract}

Key words: Plasticizers; Tensile; Puncture; Permeability; Opacity; Glycerol

\section{INTRODUCTION}

Environmental pollution and conservation has been discussed with more emphasis. Plastics are significant part of waste volume in the landfills and represent growing concern. However, plastics artifacts are part of everyday life due to its great versatility of uses. This reality is encouraging the development of alternative materials to minimize the environmental impact caused by their excessive use (Mali et al. 2010).

Studies have focused on the development of biodegradable packaging from the renewable sources and among the natural polymers, starch has become one of the most promising candidates due to its high availability, renewability and low cost (Tang et al. 2012). Starches from different sources have been investigated regarding their film formation properties (Ferreira et al. 2009; Melo et al. 2011; Maran et al. 2013). Starch shows thermoplastic behavior; however, if used pure, forms brittle films with lower flexibility requiring the addition of a plasticizer (Galdeano et al. 2009a). The plasticizer interferes in the association between polymer chains, leading to an increased flexibility of the films (Chen and Lai 2008).

The challenge in the production of the biodegradable plastics based on starch is to reduce their hydrophilic character and improve their stability under different environmental conditions. Therefore, oat starch may present advantage in comparison to other starches as it contains about 1

*Author for correspondence: allan.wilhelm@embrapa.br 
to 3\% lipids (Wang and White 1994; Galdeano et al. 2009b). This higher amount of hydrophobic material when compared to other starches can acts as a barrier to water vapor, reducing the moisture sorption and leading to less variation in the films properties at different environmental conditions.

Besides the nature of starch and its cohesive structure, type of processing, environmental conditions, type of plasticizer, their thickness and other factors determine the properties of the films (Mali et al. 2010). Control of the thickness in the films produced by casting is a step that requires great attention since variations here can affect their properties, including the mechanical and barrier properties, which certainly compromise the performance of the package (Jansson and Thuvander 2004).

In this study, the effect of thickness on the mechanical properties, opacity and water vapor permeability of oat starch films elaborated with different plasticizers and stored under different relative humidities was investigated.

\section{MATERIALS AND METHODS}

\author{
Materials \\ Oat starch was extracted from whole oat flour \\ supplied by SL Alimentos Ltda (Brazil). Starch \\ separation was done according to Lim et al. (1992) \\ using alkaline $\mathrm{pH}$ under low shear rate. All the \\ reactants used in the analyses were analytical \\ grade.
}

\section{Biofilms Production}

Biofilms with different thickness $(80,100$ and 120 $\mu \mathrm{m})$ were produced by casting using $(\mathrm{g} / 100 \mathrm{starch})$ glycerol 20, sorbitol 25, sucrose 55.5, urea 16 and glycerol:sorbitol mixture 23 as plasticizers. The plasticizers were tested in prior assays in order to determine the minimum level necessary to produce the flexible and crackless films. Their characteristics and content are shown in Table 1.

Table 1 - Plasticizer characteristics and content.

\begin{tabular}{lcccc}
\hline \multirow{2}{*}{ Plasticizer } & $\begin{array}{c}\text { Molar mass } \\
\left(\mathbf{g ~ M o l}^{\mathbf{1}}\right)\end{array}$ & $\begin{array}{c}\text { Hydroxyls } \\
\text { per } \mathbf{~ m o l}\end{array}$ & \multicolumn{2}{c}{ Plasticizer content } \\
\cline { 4 - 5 } & 92 & 3 & g/100 g starch & mol/100 g starch \\
\hline Glycerol & 182 & 6 & 20.0 & 0.217 \\
Sorbitol & 60 & 0 & 25.0 & 0.137 \\
Urea & 342 & 8 & 16.0 & 0.267 \\
Sucrose & - & - & 55.5 & 0.162 \\
Glycerol:Sorbitol $(1: 1)$ & & & 23.0 & 0.188 \\
\hline
\end{tabular}

Starch dispersions $(2.7 \% \mathrm{w} / \mathrm{v})$ and the plasticizer were heated in a Brabender Pt 100 ViscoAmyloGraph at rate of $3^{\circ} \mathrm{C} / \mathrm{min}$ up to $80^{\circ} \mathrm{C}$ and kept at this temperature for 10 minutes. Filmogenic solutions were spreaded over an acrylic plate. Control of thickness was performed by the relationship between the mass of solution and area of the plate. Material was dried to constant weight at $60^{\circ} \mathrm{C}$ in a hot air circulation oven.

\section{Films Characterization}

\section{Thickness}

The thickness was measured using a manual micrometer (MITUTOYO, Brazil) with an accuracy of $\pm 1 \mu \mathrm{m}$ at ten random positions.

\section{Apparent Opacity}

The apparent opacity was determined according to Gontard et al. (1992). The films were cut into rectangles and placed in the spectrophotometric cuvette (Visible Spectrometer GBC Cintra 20, Australia). Opacity was defined as the area under the curve determined by integration and expressed as absorbance vs. nanometers (A.nm).

\section{Water Vapor Permeability (WVP)}

The WVP tests were performed using E96 method (ASTM 1996). Each sample was sealed over a circular opening of $0.00181 \mathrm{~m}^{2}$ in a permeation cell that was stored in a desiccator at $25^{\circ} \mathrm{C}$. To maintain a gradient of $75 \%$ relative humidity $(\mathrm{RH})$ across the film, anhydrous calcium chloride $(0 \%$ $\mathrm{RH})$ was placed in the cell and a sodium chloride saturated solution $(75 \% \mathrm{RH})$ was used into the desiccator. Water vapor transport was determined from the changed weight of the permeation cell. Eight measurements were made over the $24 \mathrm{~h}$. Changes in the weight of the cell were recorded and plotted as the function of time. The slope of 
each line was calculated by linear regression and water vapor transmission rate (WVTR) was calculated from the slope of straight line $(\mathrm{g} / \mathrm{s})$ divided by cell area $\left(\mathrm{m}^{2}\right)$. The WVP $\left(\mathrm{g} \mathrm{Pa}^{-1} \mathrm{~s}^{-1} \mathrm{~m}^{-1}\right)$ was calculated as $W V P=\left[W V T R / S\left(R_{1}-R_{2}\right)\right] d$, where $S$ represented the saturation vapor pressure of water $(\mathrm{Pa})$ at the test temperature $\left(25^{\circ} \mathrm{C}\right), R_{I}$ the $\mathrm{RH}$ in the desiccator, $R_{2}$ the $\mathrm{RH}$ in the permeation cell and $d$ the film thickness (m). Under these conditions, the driving force $\left[S\left(R_{1}-R_{2}\right)\right]$ was 1753.55 Pa.

\section{Mechanical Properties}

The mechanical tests were done using a Texture Analyser TA-TX2i (Surrey, England). Tensile tests were performed according to D882-91 method (ASTM 1996) and the parameters determined were stress at the break (MPa) and strain at break (\%). For puncture tests, force $(\mathrm{N})$ and deformation $(\mathrm{mm})$ were determined and the samples were cut into square format (40 mm side) and fixed on the basis of the equipment. A $5 \mathrm{~mm}$ diameter cylindrical probe (SMS P/5) was used to penetrate the material at speed of $0.8 \mathrm{~mm} / \mathrm{s}$.
Previously, the tests materials were conditioned into $11,57,76$, and $90 \% \mathrm{RH}$ at $25^{\circ} \mathrm{C}$ for $48 \mathrm{~h}$. For each test, 25 samples were analyzed.

\section{Statistical Analysis}

The Statistica Software 5.0 (Oklahoma) was used to the variance analysis (ANOVA). Significant differences $(\mathrm{p} \leq 0.05)$ were determined using Tukey test.

\section{RESULTS AND DISCUSSION}

\section{Apparent opacity}

Figure 1 shows the apparent opacity of films. It was observed that the higher the thickness, the higher was the opacity values. However, in the films without plasticizer and in those containing glycerol:sorbitol, this effect was not observed, which could be related to the low range of thickness variation and/or to the technical difficulties in the preparation of these materials, in which variation was up to $13 \%$ in thickness.

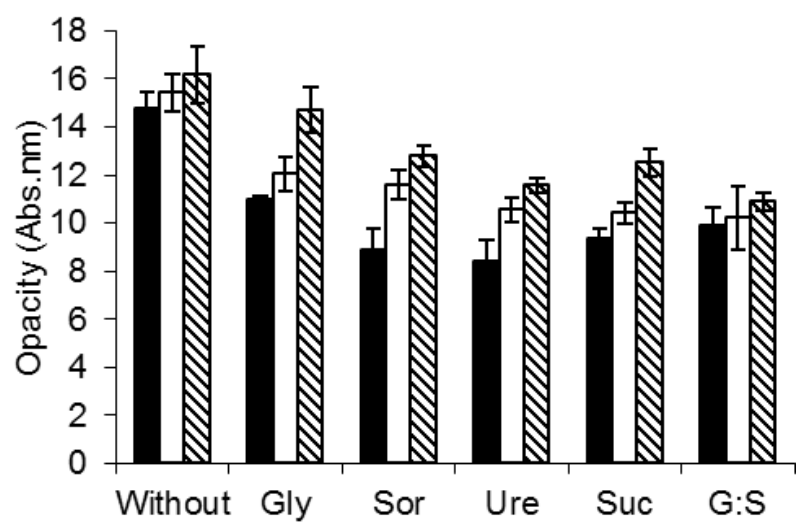

Figure 1 - Apparent opacity (Abs.nm) of oat starch films at different thickness. $\square 80 \mu \mathrm{m} ; \square 100 \mu \mathrm{m}$; $\mathbf{D}$ $120 \mu \mathrm{m}$. Without $=$ without plasticizer; Gly $=$ glycerol; Sor $=$ sorbitol; Ure $=$ urea; Suc $=$ sucrose; G:S = glycerol:sorbitol.

Films without the plasticizer were the most opaque, which be due to the proximity of the polymer chains, as between these chains, there was no other component, enabling less incident light to traverse them. Plasticized films showed no significant difference among them, which could be due to the similarity of chemical groups and molecular weight of plasticizers (Table 1). However, even for the films without the plasticizer, a good transparency was observed, indicating that oat starch films could be used in the cases where the product should be visible to the consumers.

\section{Water vapor permeability (WVP)}

In some cases, the thickness (Fig. 2) was relevant for WVP presenting an increase in permeability with increasing thickness. In the films plasticized with glycerol, sorbitol and combination of both, the WVP was not affected by the thickness as also observed by Longares et al. (2004). In the films without plasticizer and in those containing sucrose, 
the WVP was lower when the thickness was 80 $\mu \mathrm{m}$. Urea films were more permeable when thickness was $120 \mu \mathrm{m}\left(4.916 \times 10^{-12} \mathrm{~g} \mathrm{~m}^{-1} \mathrm{~s}^{-1} \mathrm{~Pa}^{-1}\right)$. Increased permeability due to increased thickness was also observed by Sobral (1999). According to Fick's law, permeability is inversely proportional to thickness showed in synthetic films. Deviation of this ideal behavior indicated that starch films have an affinity for water, which was not considered in the law.

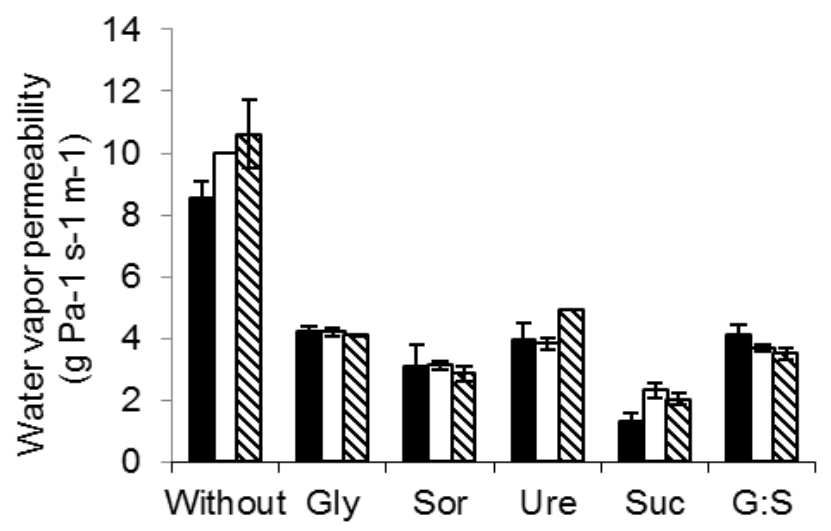

Figure 2 - Water vapor permeability $\left(\mathrm{g} \mathrm{m}^{-1} \mathrm{~s}^{-1} \mathrm{~Pa}^{-1}\right)$ of oat starch films at different thickness. $80 \mu \mathrm{m} ; \square 100$ $\mu \mathrm{m} ; \mathbf{\nabla} 120 \mu \mathrm{m}$. Without = without plasticizer; Gly = glycerol; Sor = sorbitol; Ure = urea; Suc = sucrose; G:S = glycerol:sorbitol.

Several explanations of the effect of thickness on the WVP in starch films have been reported. McHugh et al. (1993) observed that when the thickness increased, the film provided higher resistance to mass transfer through it, thus the partial vapor pressure in equilibrium in internal surface of the film increased. According to Park and Chinnan (1995), the hydrophilic films show positive relationship between the thickness and permeability due to the interaction of water with the polymer matrix that occurs due to the structural changes caused by the swelling of the hydrophilic matrix. This affects the film structure and cause internal tensions that influence the permeation.

\section{Tensile Properties}

Figures 3 and 4 show the effect of thickness on the stress at break and strain at break of oat starch films stored at different RH. In general, tensile properties did not change with increasing the thickness, which could be due to the low range of thickness variation studied. However, in some cases, thickness was relevant and the results were according to the tendency that thicker films need more strength to be broken and have higher elongation. In thicker films, the polymer matrix is denser and rich in inter and intramolecular interactions and, consequently, more resistant to rupture (Mali et al. 2005a).

Sorbitol films (Fig. 3) at $80 \mu \mathrm{m}$ thick (11\% RH) were less resistant than the films at 100 and 120 $\mu \mathrm{m}$. Under $90 \% \mathrm{RH}$, the films containing glycerol at 80 and $100 \mu \mathrm{m}$ showed tensile strength of 2.2 $\mathrm{MPa}$, while at $120 \mu \mathrm{m}$, the value was $3.6 \mathrm{MPa}$; urea films at $120 \mu \mathrm{m}$ were more resistant than the thinner films.

Increase in elongation with increasing thickness of the films (Fig. 4) was seen in glycerol:sorbitol films at all RHs in the films containing sucrose at $11 \% \mathrm{RH}$ and in sorbitol films at 57\% RH. Mali (2002), also studying starch films, reported an increase in elongation with increasing thickness. However Janson and Thuvander (2004) observed opposite effect, a decrease from 100 to $20 \%$ in elongation with increasing thickness 0.3 to 2.5 $\mathrm{mm}$. These results could be explained by the large difference in the thickness among the materials. 

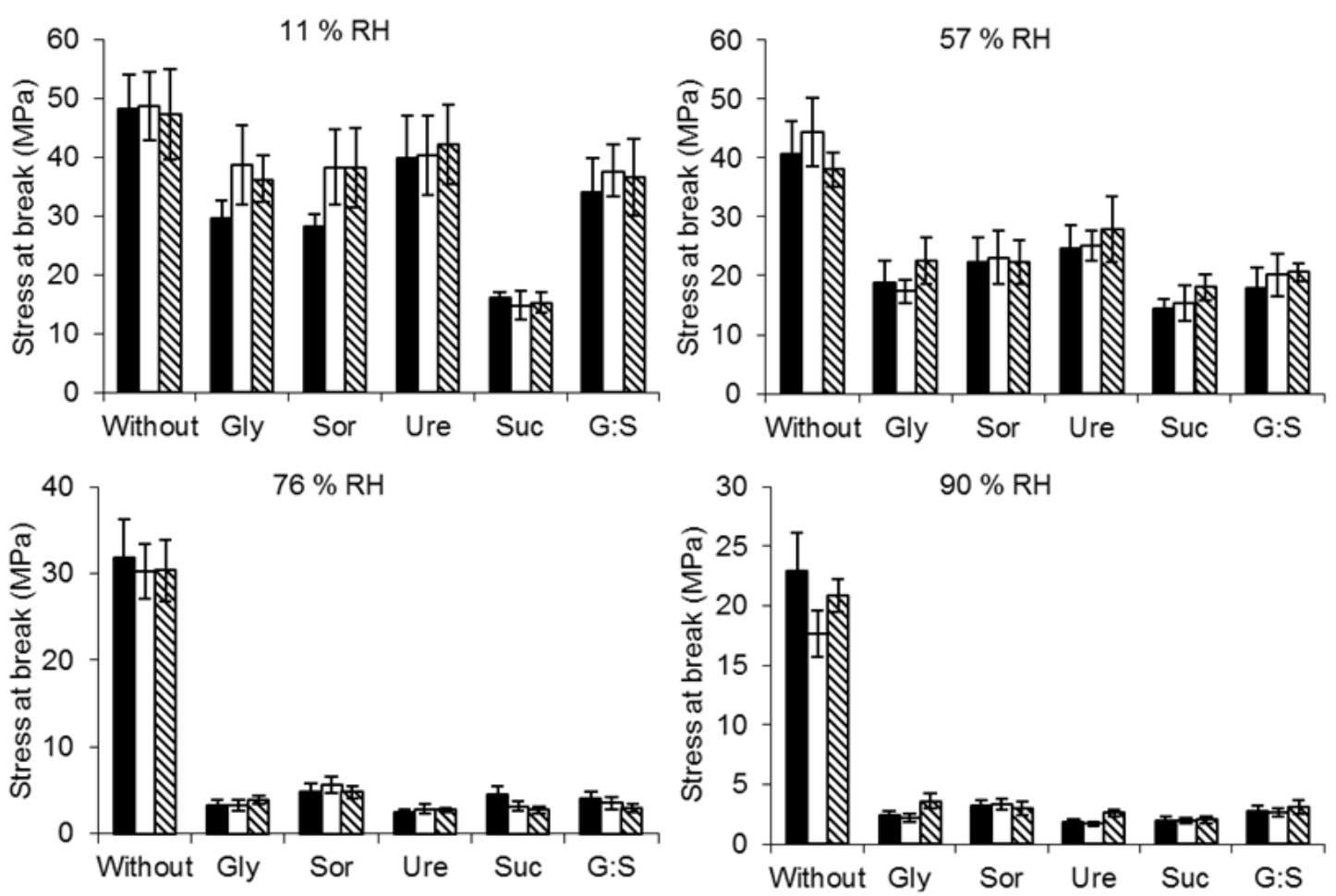

Figure 3 - The effect of thickness in stress at break of oat starch films at different RH. $\square 80 \mu \mathrm{m}$; $\square 100 \mu \mathrm{m} ; \mathbf{\nabla} 120 \mu \mathrm{m}$. Without = without plasticizer; Gly = glycerol; Sor = sorbitol; Ure $=$ urea; Suc $=$ sucrose $; \mathrm{G}: \mathrm{S}=$ glycerol:sorbitol.
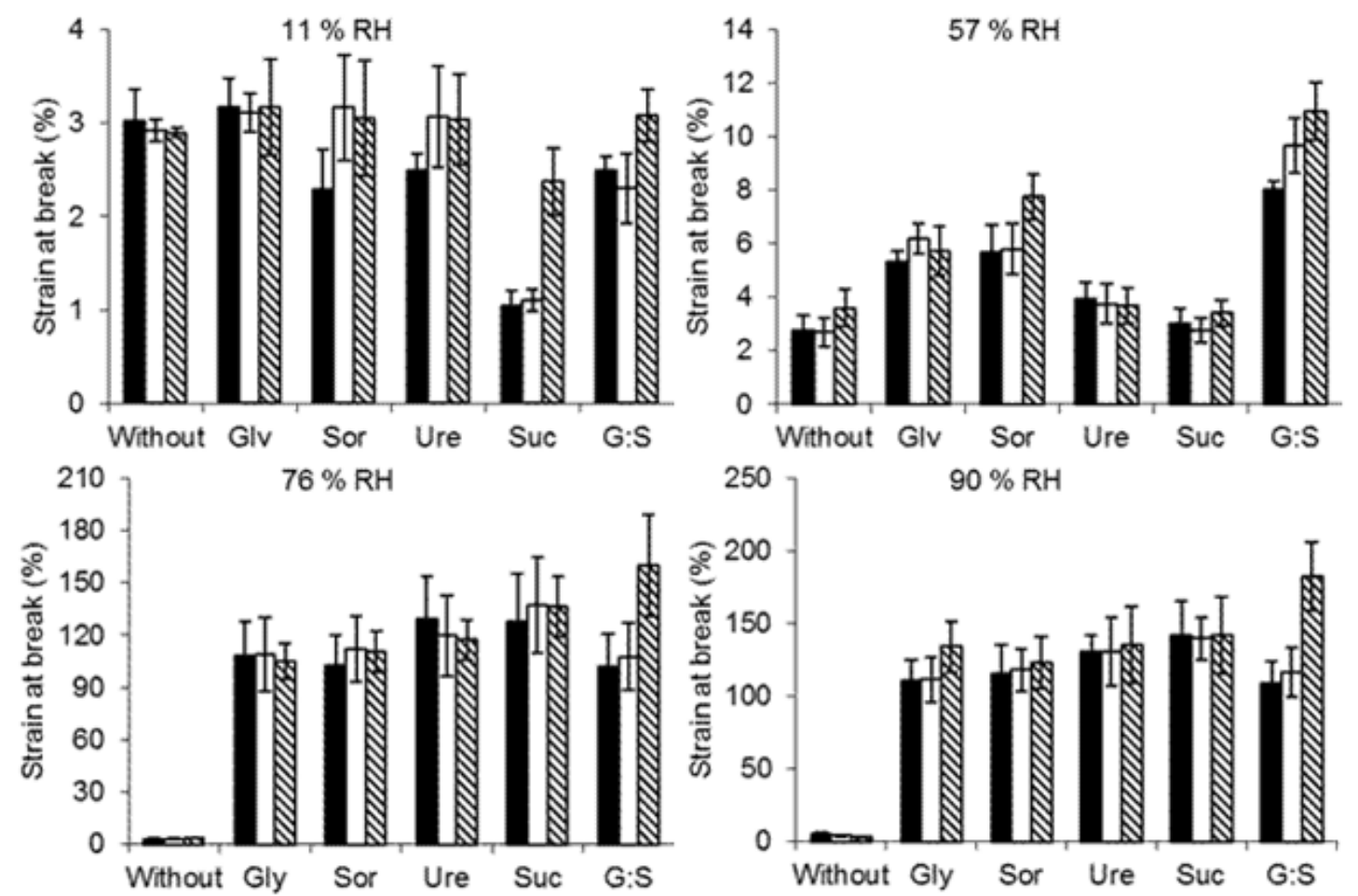

Figure 4 - The effect of thickness on strain at break of oat starch films at different RH. $\square 00 \mu \mathrm{m}$; $\square 100 \mu \mathrm{m} ; \mathbf{N} 120 \mu \mathrm{m}$. Without = without plasticizer; Gly = glycerol; Sor = sorbitol; Ure = urea; Suc = sucrose; G:S = glycerol:sorbitol. 


\section{Puncture properties}

Unlike seen in tensile properties, variation in the thickness affected the puncture properties of the films (Figures 5 and 6). Results were in agreement with the tendency that the films with higher thickness required more force to be punctured and had higher deformation. Exception occurred in the films plasticized with sucrose as thickness increase did not affect the strength needed to punch. The effect of that increased thickness needs higher puncture force could be explained by the larger amount of dry matter per area, which led to more molecular interactions (Cuq et al. 1996). Cases where increase in the thickness was significant to puncture force fitted to linear regression (Table 2).
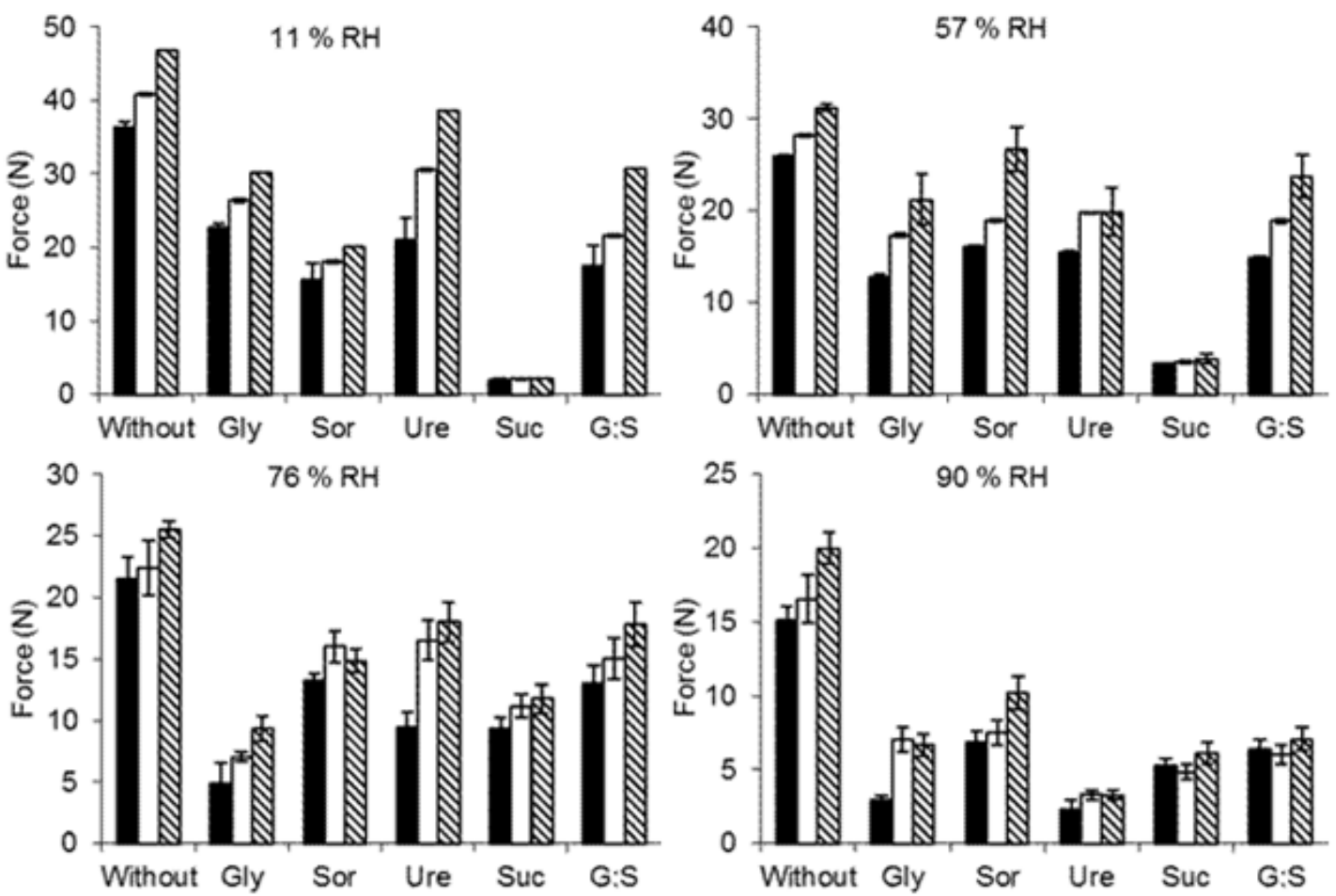

Figure 5 - The effect of thickness on puncture force $(\mathrm{N})$ of oat starch films at different relative humidity (RH). $\quad 80 \mu \mathrm{m} ; \square 100 \mu \mathrm{m}$; $\mathbf{\nabla} 120 \mu \mathrm{m}$. Without = without plasticizer; Gly = glycerol; Sor = sorbitol; Ure = urea; Suc = sucrose; G:S = glycerol:sorbitol.

Table 2 - Parameters of linear regression adjusted for puncture force of oat starch films.

\begin{tabular}{|c|c|c|c|c|c|c|c|c|}
\hline \multirow{3}{*}{ Plasticizer } & \multicolumn{8}{|c|}{ Relative humidity (\%) } \\
\hline & \multicolumn{2}{|c|}{11} & \multicolumn{2}{|c|}{57} & \multicolumn{2}{|c|}{76} & \multicolumn{2}{|c|}{90} \\
\hline & B & $\mathbf{R}^{2}$ & B & $\mathbf{R}^{2}$ & B & $\mathbf{R}^{2}$ & B & $\mathbf{R}^{2}$ \\
\hline Without & 0.2638 & 0.9936 & 0.1333 & 0.9905 & 0.1003 & 0.9113 & 0.1218 & 0.9430 \\
\hline Glycerol & 0.1883 & 0.9998 & 0.2109 & 0.9982 & 0.1126 & 0.9996 & 0.0923 & 0.6818 \\
\hline Sorbitol & n.s. & n.s. & 0.2659 & 0.9334 & n.s. & n.s. & 0.0839 & 0.8878 \\
\hline Urea & 0.4367 & 0.9976 & 0.1102 & 0.7723 & 0.2144 & 0.8766 & n.s. & n.s. \\
\hline Sucrose & n.s. & n.s. & n.s. & n.s. & n.s. & n.s. & n.s. & n.s. \\
\hline Glycerol:Sorbitol & 0.3307 & 0.9543 & 0.2217 & 0.9970 & 0.1195 & 0.9897 & n.s. & n.s. \\
\hline
\end{tabular}

$\mathrm{B}=$ slope coefficient; $\mathrm{R}^{2}=$ determination coefficient; n.s. = not significant.

Comparing the slope coefficients, it was observed that higher thickness caused less significant increase in the puncture force in the films at $90 \%$ UR, which was demonstrated by the lower B values. In contrast, the most significant effects were noticed in the films stored under $11 \% \mathrm{RH}$, as observed in the films without the plasticizer $(B=0.2638)$, containing urea $(B=0.4367)$ and 
containing glycerol:sorbitol $(\mathrm{B}=0.3307)$. The most significant influence of the thickness for glycerol and sorbitol films was reached at 57\% UR ( $B=0.2109$ and 0.2659 , respectively). As observed in Table 2, thickness was not significant to puncture force in the films plasticized with sucrose at any storage UR.

Deformation tests (Fig. 6) indicated that at $11 \%$ $\mathrm{RH}$, the films plasticized with urea at $120 \mu \mathrm{m}$ were more deformable than at 80 and $100 \mu \mathrm{m}$. At $57 \%$ $\mathrm{RH}$, the thicker films with sorbitol, sucrose and glycerol:sorbitol mixture were also more deformable. At $90 \% \mathrm{RH}$, this effect was observed in the films plasticized with urea, glycerol and glycerol:sorbitol. Mali (2002) reported deformation of 1.5 and $1.9 \mathrm{~mm}$ for yam starch films with thicknesses of 0.07 and $0.11 \mathrm{~mm}$, respectively. However, Sobral (1999) demonstrated that deformation puncture remained constant with increasing biofilms thickness, with values around $4 \%$.
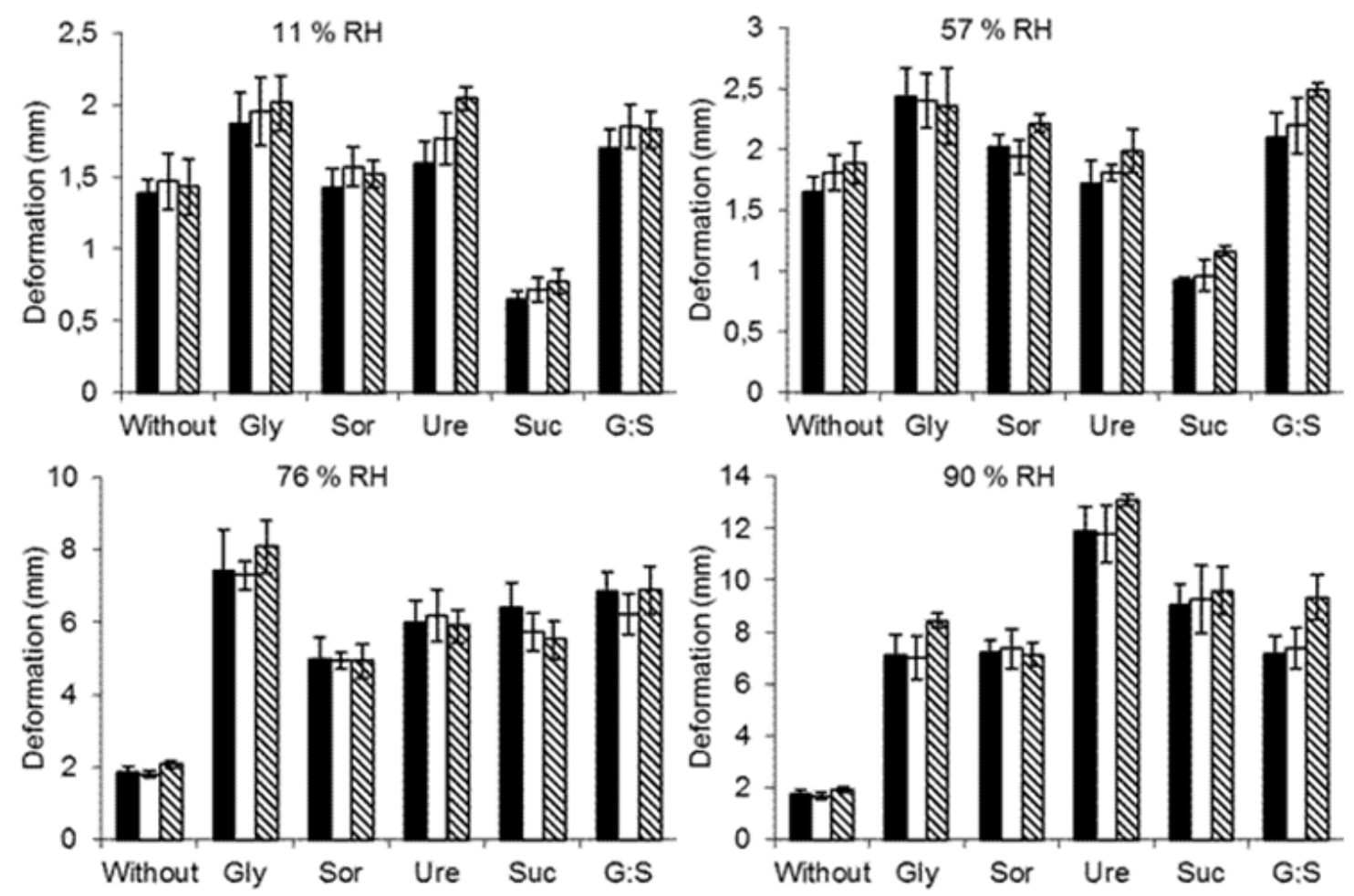

Figure 6 - Effect of thickness on puncture deformation $(\mathrm{mm})$ of oat starch films at different relative humidity (RH). $\square 80 \mu \mathrm{m} ; \square 100 \mu \mathrm{m} ; \mathbf{N} 120 \mu \mathrm{m}$. Without = without plasticizer; Gly = glycerol; Sor = sorbitol; Ure = urea; Suc = sucrose; G:S = glycerol:sorbitol.

\section{CONCLUSION}

Opacity values increased with increasing the thickness and films without the plasticizer were the most opaque. Glycerol:sorbitol films presented increased elongation with increasing thickness in all RH. Puncture force was dependent on the thickness of the films, except for those plasticized with sucrose. In general, thickness did not affect the water vapor permeability, which could be due to the low range variation of the thickness studied.

\section{ACKNOWLEDGEMENTS}

The authors would like to express their gratitude to SL Alimentos Ltda. 


\section{REFERENCES}

American Society for Testing and Material (ASTM). Standard test method for tensile properties of thin plastic sheeting, D882-91. In Annual book of ASTM. Philadelphia (USA): ASTM; 1996.

Chen C-H, Lai L-S. Mechanical and water vapor barrier properties of tapioca starch/decolorized hsian-tsao leaf gum films in the presence of plasticizer. Food Hydroc. 2008; 22(8): 1584-1595.

Cuq B, Gontard N, Cuq JL, Guilbert, S. Functional properties of myofibrillar protein based biopackaging as affected by film thickness. J Food Sci. 1996; 61(3): 580-584.

Ferreira FAB, Grossmann MVE, Mali S, Yamashita F, Cardoso LP. Effect of relative humidities on microstructural, barrier and mechanical properties of yam starch-monoglyceride films. Braz Arch Biol Technol. 2009; 52(6): 1505-1512.

Galdeano MC, Grossmann MVE, Mali S, Bello-Perez LA, Garcia MA, Zamudio-Flores PB. Effects of production process and plasticizers on stability of films and sheets of oat starch. Mat Sci and Eng: C. 2009b; 29(2): 492-498.

Galdeano MC, Mali S, Grossmann MVE, Yamashita F, García MA. Effects of plasticizers on the properties of oat starch films. Mat Sci and Eng: C. 2009a; 29(2): 532-538.

Gontard N, Guilbert S, Cuq J-L. Edible Wheat Gluten Films: Influence of the main process variables on film properties using response surface methodology. J of Food Sci. 1992; 57(1): 190-195.

Jansson A, Thuvander F. Influence of thickness on the mechanical properties for starch films. Carbohyd Polym. 2004; 56: 499-503.

Lim WJ, Liang YT, Seib PA, Rao CS. Isolation of oat starch from oat flour. Cereal Chem. 1992; 69(3): 233-236.

Longares A, Monahan FJ, O'Sullivan M, O'Riordan ED. Physical properties and sensory evaluation of WPI films of varying thickness. LebensmittelWissenschaft und-Technologie. 2004; 37(5): 545-550.
Mali S, Grossmann MVE, Garcia MA, Martino MN, Zaritzky NE. Mechanical and thermal properties of yam starch films. Food Hydroc. 2005a; 19: 157-164.

Mali S, Grossmann MVE, Yamashita F. Filmes de amido: produção, propriedades e potencial de utilização. Semina: Cienc Agrar. 2010; 31(1): 137156.

Mali S. Produção, caracterização e aplicação de filmes plásticos biodegradáveis a base de amido de cará [Tese de doutorado] Londrina, Brasil: Universidade Estadual de Londrina; 2002.

Maran JP, Sivakumar V, Sridhar R, Thirugnanasambandham K. Development of model for barrier and optical properties of starch based edible films. Carbohyd Polym. 2013; 92: 1335-1347.

McHugh TH, Avenna-Bustillos R, Krochta JM. Hydrophilic edible films: modified procedure for water vapor permeability and explanation of thickness effects. J Food Sci.1993; 58(4): 899-903.

Melo C, Garcia PS, Grossmann MVE, Yamashita F, Dall'Antônia LH, Mali S. Properties of extruded xanthan-starch-clay nanocomposite films. Braz Arch Biol Technol. 2011; 54(6): 1223-1333.

Park HJ, Chinnan MS. Gas and water vapor barrier properties of edible films from protein and cellulosic materials. J of Food Eng. 1995; 25(4): 497-507.

Sobral PJA. Propriedades funcionais de biofilmes de gelatina em função da espessura. Ciênc \& Eng. 1999; 8(1): 60-67.

Tang XZ, Kumar P, Alavi S, Sandeep KP. Recent advances in biopolymers and biopolymer-based nanocomposites for food packaging materials. Crit Rev Food Sci \& Nutr. 2012; 52(5): 426-442.

Wang LZ, White PJ. Structure and properties of amylose, amylopectin, and intermediate materials of oats starch. Cereal Chem. 1994; 71(3) 263-268.

Received: February 06, 2012; Accepted: June 11, 2013 